\title{
Can and should nuclear weapons be fully abolished?
}

\author{
Katja Putseys \\ MSc in Global Crime, Justice and Security
}

Nuclear weapons are weapons of mass destruction, and as such differ from regular weapons in the magnitude of their destructive power and reach. Nuclear explosions may unleash a thousand (potentially million) times more destructive power than conventional weapons (Siracusa 2008, p. 21). This is estimated based on the sheer magnitude of their impact, the expanse of their destructive power as well as their long-term effects. Nuclear weapons have the potential to destroy entire cities and yet, our preconceived idea about them is that they are a key feature of national and international security. This seems rather counterintuitive. In this commentary, I will establish the rationale behind our moral responsibility to abolish nuclear weapons, whilst arguing that the transition to a nuclear-weapons free world is not a realistic outcome. I will highlight how nuclear weapons are inefficient in guaranteeing security, especially given the possibility of human and technical errors occurring. Under a realist lens of human nature, presupposed conflict is a likely scenario. As such, nuclear weapons would serve as a deterrent to prevent said conflicts. Nuclear weapons cannot be un-invented', and with the possibility that civilians might misuse nuclear energy, abolishing these weapons becomes unfeasible (Bourne 2016). It is up to states to make the decision of whether the world can become non-nuclear, which does not seem currently likely.

First, we must look at the question of whether nuclear weapons should be fully abolished or not. The term 'should' implies a sense of morality and practicality, as opposed to a question of 
possibility. It does not ask us if we can eliminate nuclear weapons, rather it asks if it is the right thing to do. A key argument against the abolishment of nuclear weapons is that of nuclear deterrence and its benefits. Deterrence, as defined by George and Smoke (1974), is 'simply the persuasion of one's opponent that the costs and/or risks of a given course of action $[\ldots]$ outweigh its benefits' (cited in Wilson 2008, p. 422). The main assumption here is that nuclear deterrence works, since any incoming/imminent attack on a nuclear state would result in nuclear retaliation. The resulting tit-for-tat moves lead to nuclear warfare and fundamental devastation. This would imply not only damage to architecture, cities or countries, but also great environmental repercussions (Doyle 2013). The most poignant example of the deterrent capability of nuclear weapons is the Cold War. Due to the fear of Mutually Assured Destruction (MAD) between the United States (US) and the Soviet Union (USSR), the two countries were disincentivised to attack each other despite frequent provocations. MAD was a doctrine of international security, in which the use of nuclear weapons by one nation against another could result in the complete annihilation of all parties involved. The shadow of nuclear retaliation and subsequent nuclear war deterred the two superpowers from attacking one another. Interestingly though, when we look at the AntiBallistic Missile Treaty, we can observe that MAD was not necessarily a naturally occurring phenomenon. The treaty was born out of a discrepancy between the US and USSR anti-ballistic missile (ABM) capabilities. In essence, the USSR developed ABM systems which allowed them to intercept potential US nuclear missiles and therefore fend off an attack; much to the dismay of the US which was lacking behind in ABM development (Grynaviski 2010). Amid Soviet uncertainty regarding the potency of US ABM systems, US and Soviet representatives negotiated a limit on these defensive capabilities. With limited defence, destruction was truly mutually assured. The history of the ABM treaty shows that MAD is not inherent to nuclear proliferation and required an institutionalised legal framework (Yoo 2001). In other words, MAD needed to be constructed as opposed to being a natural consequence of nuclear weapons proliferation.

Even if nuclear weapons had an intrinsic deterrent capacity, deterrence is not necessarily as effective as initially perceived. Deterrence is assumed to be effective because of the prevalent notion that the safety of civilians influences military campaigns (Wilson 2008). However, if we look at the bombings on civilians during the Second World War (WWII), we can observe that neither Germany nor Britain were ever inclined to surrender to protect their people. Bombing campaigns shifted their targets from soldiers and military infrastructure to civilian infrastructure 
(ibid.). The assumption that military decisions are invariably influenced by civilian casualties is therefore flawed. Of course, it is difficult to compare conventional deterrence such as the WWII example with nuclear deterrence. Conventional weapons during WWII were significantly less destructive than nuclear weapons during the Cold War. As such, it could be argued that given the much larger scale of the damage potentially caused by a nuclear weapon, they would be more likely to facilitate deterrence. However, upon examining the case of Japan, it is unclear as to whether it was the nuclear bombs (which were the climax of an already long-lasting bombing campaign on Japanese cities) or the declaration of war from the Soviet Union that incited surrender (ibid.). Tying Japan's decision to surrender to the destruction of Hiroshima and Nagasaki is therefore a weak link. Instead, Japan's surrender is more likely related to an array of factors such as the improbability of meaningful military gains considering the surrender of Japan's allies. All of this suggests that nuclear attacks on civilians do not necessarily affect military morale nor do they seem to matter much to heads of state. If this is the case, it is safe to assume that deterrence is not guaranteed to be successful, therefore the primary purpose of nuclear weapons is eliminated. If nuclear weapons no longer have a purpose, then they should be abolished as they become futile tools.

I will now examine the role of human and technical error, in the argument for nuclear weapon abolishment this factor supports the argument for abolishment. In their work, Lewis et al. (1995) examine 13 cases of 'near misses,' in which nuclear weapons were almost launched as a result of misunderstandings, miscommunications, and technical failures. Notable examples include the 1962 Operation Anadyr failure, the 1980 NORAD faulty computer chip case, and the 1991 Kargil Crisis. A detailed account of these events can be found in Lewis et al.'s (ibid.) study. These cases have a crucial commonality: they attest to how nuclear catastrophes can still occur due to factors outside of political control or military strategy. A weapon can be detonated either accidentally or deliberately, due to miscommunication. Although there are many safeguards in place to reduce this risk, it is impossible to eliminate the factor of human and technical error. Therefore, it is impossible to totally eradicate the risk of accidental nuclear launches which may be misinterpreted as attacks. This is another moral justification for abolishment. The consequences that result from human and technical error would arguably be more catastrophic than any other conventional weapon. 
I would like to point out that, even if nuclear weapons are assured by states to be used solely for the purpose of deterrence, there is no guarantee that they will not be used when faced with an emergency (Doyle 2013). The realist school of political thought has been the most influential when informing nuclear doctrine, and as such it is important to examine where it stands regarding nuclear weapons (Bull 1968). The realist perspective considers the state to be the principal actor in international relations. Furthermore, the main focus of international politics is state power through which states achieve security. Realist thought also suggests that it is within human nature to be prone to conflict (Morgenthau 1948, p. 17). If this is the case, one could assume that it is perfectly within the realm of human nature to utilise weapons of mass destruction in order to gain power or security, especially if the state is perceived to be threatened. As alluded to earlier, proponents of nuclear weapons have suggested that rational states would be deterred from utilising these weapons in fear of retaliation. This could be misleading, as we have seen in numerous occasions how nuclear states have continued to use their military might against other nuclear states, which could potentially have led to large-scale conflict (Doyle 2013). Doyle (ibid.) highlights how nuclear weapons did not prevent the North Atlantic Treaty Organization (NATO) from using military force in Kosovo for example, or Egypt and Syria from attacking Israel. In other words, what starts as a conventional war may escalate into nuclear warfare. Taking this into account, one must conclude that nuclear weapons pose too great a danger in a realist world and as such must be abolished.

I will now tackle the second half of the question, 'can nuclear weapons be fully abolished?' This is a question of possibility.

The possibility of nuclear disarmament is easily countered by the idea that nuclear weapons cannot cease to exist, as they cannot be 'un-invented' (Bourne 2016). This is an intuitive assumption which implies invention is irreversible (ibid.). Invention is 'the building of a pathway, assembling a unity of action from disparate elements' (ibid., p. 14). Therefore, un-invention must be the reversal and elimination of this process. Due to the scope of this essay, I will only focus on tacit knowledge with reference to un-invention and the counter argument for it.

It is likely that if disarmament were to take place, the knowledge of how to build nuclear weapons would prevail. This implies that said knowledge is tacit as opposed to explicit. Explicit knowledge can be recorded and stored in the form of symbols and words, whereas tacit knowledge 
is gained from practice and experience (MacKenzie \& Spinardi 1995). Tacit knowledge is an important part of invention, especially in the case of nuclear weapons, as seen in MacKenzie and Spinardi's work (1995). It could be then argued that if experimentation was halted and no one continued to participate in these investigations, this practical knowledge would be lost over time. However, this assumption is inaccurate. Although tacit knowledge is important, it would merely take longer to obtain this knowledge through repetition of practice. It would still be achievable as it was the first time, meaning that un-invention cannot have taken place. In fact, the idea of uninvention seems largely counter-intuitive. Once an idea, process, or creation has come to be, the process of invention cannot be reversed. In simple terms, even if nuclear weapons were to be eliminated and the knowledge on how to create them had ceased to exist, the fact remains that these weapons had once been invented and therefore existed. Re-invention is thus a more likely scenario, whereby nuclear weapons technology could perhaps gain a new and more peaceful purpose (Bourne 2016).

Nuclear disarmament promises to come with iron-clad verification processes, to ensure no state is utilising or building nuclear weapons. This should in theory placate fears of states producing these weapons illegally. However, taking into consideration the case of Iran and the ambiguity of their nuclear programme, we can understand how verification becomes complicated. Iran - along with other states - utilises nuclear reactors to produce energy. This in itself is not a problem, however the materials used in nuclear reactors and the materials produced by them have the capability to power nuclear bombs (Barzashka \& Oelrich 2012). While the Non-Proliferation Treaty (NPT) prescribes a monitoring system to ensure nuclear material is used for energy purposes exclusively, it does not provide any method of actively stopping or preventing these materials being used as weapons (ibid.). Therefore, there is always the possibility for nuclear energy producing states to accrue nuclear material, and subsequently create a nuclear weapon illegally before the monitoring system detects it. This is because work on nuclear weapons can occur in computers or small-scale laboratories which are capable of evading national surveillance (ibid.). This situation is not unique to Iran, and so we must conclude that for as long as nuclear materials are used for energy, there will always be the possibility of a nuclear bomb being built. This danger makes it highly unlikely that nuclear abolishment can occur, as states will not be incentivised to give up their own nuclear weapons as long as nuclear energy producing states may have weapons on their own. 
Finally, there has been an increase in the number of non-governmental initiatives and appeals made to the abolishment of nuclear weapons and states themselves have begun to show a willingness to partake in this. As seen in Granoff's work (2009), Germany's Foreign Minister Guido Westerwelle, appealed for the removal of all NATO nuclear weapons from German soil. He suggested that these weapons were outdated relics of the Cold War and that by eliminating them, they would set a precedent for Europe to follow suit (ibid.). It is also implied that a US led nuclear disarmament initiative would be enthusiastically followed by other states. This is also the case in Japan, suggesting there is widespread agreement on the importance of nuclear disarmament. In 2017, a majority of United Nations member states voted for a proposed treaty agreeing to ban nuclear weapons. This would imply a growing awareness of the detrimental effects that the possession of nuclear weapons entails, and in an ideal world leading to the eventual abolishment thereof. However, the current political situation regarding nuclear weapons suggests otherwise. Three states; namely the United States, the United Kingdom, and France have refused to sign this treaty and have published whitepapers stating that they refuse to agree to these terms, in order to ensure national and public safety (United States Mission to the United Nations 2017). This would suggest that although some states are keen on the idea of nuclear disarmament, certain key, powerful nuclear states are not since nuclear weapons are viewed as essential to their national security. It is impossible to ban nuclear weapons if there is no consensus among states, particularly powerful states such as those mentioned.

To conclude, this paper has demonstrated that nuclear weapons should be abolished as their deterrent capability is put into question by the evidence provided. Furthermore, they pose much too high a risk when human and technical errors are acknowledged If their primary purpose of deterrence does not work, if they are susceptible to the aforementioned errors, and human nature cannot be trusted, then they pose more of a risk than a safeguard. However, there is little evidence to suggest that abolishing nuclear weapons is likely in practical terms due to; the impossibility to un-invent these weapons, the issue of certain verification in states utilising nuclear energy, and importantly the unwillingness of powerful states to give up their nuclear weapons. In short, although there is a strong rationale for nuclear weapons to be abolished, in practice it is a highly unlikely scenario. Therefore, through a realist lens this will not happen, certainly not in the foreseeable future. 


\section{References}

Barzashka, I \& Oelrich, I 2012, 'Iran and Nuclear Ambiguity', Cambridge Review of International Affairs, vol. 25, no. 1, pp. 1-26, DOI 10.1080/09557571.2012.656457.

Bourne, M 2016, 'Invention and Uninvention in Nuclear Weapons Politics', Critical Studies on Security, vol. 4, no.1, pp. 6-23, DOI 10.1080/21624887.2015.1106427.

Bull, H 1968, 'Strategic Studies and Its Critics', World Politics, vol. 20, no. 4, pp. 593-605, DOI $10.2307 / 2009685$.

Doyle, JE 2013, 'Why Eliminate Nuclear Weapons?', Survival: Global Politics and Strategy, vol. 4, no. 1, pp. 7-34, DOI 10.1080/00396338.2013.767402.

Granoff, J 2009, 'The Process of Zero', World Policy Journal, vol. 26, no. 4, pp. 85-93, DOI 10.1162/wopj.2010.26.4.85.

Grynaviski, E 2010, 'Necessary Illusions: Misperception, Cooperation, and the Anti-Ballistic Missile Treaty', Security Studies, vol. 19, no. 3, pp. 376-406, DOI $\underline{10.1080 / 09636412.2010 .503512 .}$.

Lewis, P, Williams, H, Pelopidas, B \& Aghlani, S 2014, Too Close for Comfort, Cases of Nuclear Use and Options for Policy, Chatham House, London.

MacKenzie, D \& Spinardi, G 1995, 'Tacit Knowledge, Weapons Design, and the Uninvention of Nuclear Weapons', American Journal of Sociology, vol. 101, no. 1, pp. 44-99, DOI $\underline{10.1086 / 230699 .}$.

Morgenthau, HJ 1948, Politics Among Nations: The Struggle for Power and Peace, Alfred A. Knopf, New York.

Siracusa, JM 2008, Nuclear Weapons: A very short Introduction, Oxford University Press, Oxford.

United States Mission to the United States 2017, 'Joint Press Statement from the Permanent Representatives to the United Nations of the United States, United Kingdom, and France Following the Adoption', accessed 17 August 2020, $<$ https://usun.usmission.gov/jointpress-statement-from-the-permanent-representatives-to-the-united-nations-of-the-unitedstates-united-kingdom-and-france-following-the-adoption/>. 
Wilson, W 2008, 'The Myth of Nuclear Deterrence', The Non-Proliferation Review, vol. 15, no. 3, pp. 421-439, DOI 10.1080/10736700802407101.

Yoo, J 2001, 'Politics as Law?: The Anti-Ballistic Missile Treaty, the Separation of Powers, and Treaty Interpretation', California Law Review, vol. 89, no. 3, pp. 851-916, DOI $\underline{10.2307 / 3481184 .}$. 